\title{
Glyceraldehyde-3-Phosphate Dehydrogenase Is a GABA Receptor Kinase Linking Glycolysis to Neuronal Inhibition
}

\author{
Jacques J. Laschet, ${ }^{1,2}$ Frédéric Minier, ${ }^{2}$ Irène Kurcewicz, ${ }^{1}$ Michel H. Bureau, ${ }^{2}$ Suzanne Trottier, ${ }^{1}$ Freddy Jeanneteau, ${ }^{1}$ \\ Nathalie Griffon, ${ }^{1}$ Bart Samyn, ${ }^{3}$ Jozef Van Beeumen, ${ }^{3}$ Jacques Louvel, ${ }^{1}$ Pierre Sokoloff, ${ }^{1}$ and René Pumain ${ }^{1}$ \\ ${ }^{1}$ Laboratory of Molecular Neurobiology and Pharmacology, Institut National de la Santé et de la Recherche Médicale Unité 573, F-75014 Paris, France, \\ ${ }^{2}$ Laboratory of Neurosciences, University of Rennes 1, F-35000 Rennes, France, and ${ }^{3}$ Laboratory of Protein Biochemistry and Protein Engineering, \\ University of Ghent, B-9000 Ghent, Belgium
}

Protein phosphorylation is crucial for regulating synaptic transmission. We describe a novel mechanism for the phosphorylation of the $\mathrm{GABA}_{\mathrm{A}}$ receptor, which mediates fast inhibition in the brain. A protein copurified and coimmunoprecipitated with the phosphorylated receptor $\alpha 1$ subunit; this receptor-associated protein was identified by purification and microsequencing as the key glycolytic enzyme glyceraldehyde-3-phosphate dehydrogenase (GAPDH). Molecular constructs demonstrated that GAPDH directly phosphorylates the long intracellular loop of $\mathrm{GABA}_{\mathrm{A}}$ receptor $\alpha 1$ subunit at identified serine and threonine residues. GAPDH and the $\alpha 1$ subunit were found to be colocalized at the neuronal plasma membrane. In keeping with the GAPDH/GABA $\mathrm{A}$ receptor molecular association, glycolytic ATP produced locally at plasma membranes was consumed for this $\alpha 1$ subunit phosphorylation, possibly within a single macrocomplex. The membrane-attached GAPDH is thus a dual-purpose enzyme, a glycolytic dehydrogenase, and a receptor-associated kinase. In acutely dissociated cortical neurons, the rundown of the $\mathrm{GABA}_{\mathrm{A}}$ responses was essentially attributable to a $\mathrm{Mg}^{2+}$-dependent phosphatase activity, which was sensitive to vanadate but insensitive to okadaic acid or fluoride. Rundown was significantly reduced by the addition of GAPDH or its reduced cofactor NADH and nearly abolished by the addition of its substrate glyceraldehyde-3-phosphate (G3P). The prevention of rundown by G3P was abolished by iodoacetamide, an inhibitor of the dehydrogenase activity of GAPDH, indicating that the $\mathrm{GABA}_{\mathrm{A}}$ responses are maintained by a glycolysis-dependent phosphorylation. Our results provide a molecular mechanism for the direct involvement of glycolysis in neurotransmission.

Key words: $\mathrm{GABA}_{\mathrm{A}}$ receptor phosphorylation; response rundown; receptor-associated kinase; GAPDH; glycolysis; ATP

\section{Introduction}

The control of neuronal excitability is essential for brain function and depends on a continuous supply of glucose (Sokoloff, 1977). In vivo brain imaging shows tissue uptake of glucose in excess of that consumed by oxidative metabolism (Fox et al., 1988), indicating that the anaerobic glycolytic-produced ATP may preferentially serve specific nerve cell functions. Indeed, it has been suggested that glycolysis supports excitatory neurotransmission in the retina (Ames et al., 1992) and that it ensures maximal glutamate accumulation into presynaptic vesicles (Ikemoto et al., 2003).

Protein phosphorylation is a major mechanism for regulating ligand-gated ion channels (Levitan, 1999). In the mammalian brain, fast synaptic inhibition is mainly mediated by the GABA type A receptor $\left(\mathrm{GABA}_{\mathrm{A}} \mathrm{R}\right)$, which is constituted of heterooligomeric assemblies of five subunits, mostly of the $\alpha, \beta$, and $\gamma$ type, each including four transmembrane-spanning domains

\footnotetext{
Received March 10, 2004; revised June 29, 2004; accepted July 1, 2004.

We thank A. Le Treut and J. Y. Le Gall for laboratory facilities, A. Minet and B. Evrard for assistance, M. Debray for advice on statistics, W. Sieghart for the gift of antibody, and C. Loudes, A. Faivre, P. Dournaud, and A. Vincent for cell cultures. B. Turak edited this manuscript.

Correspondence should be addressed to Dr. Jacques J. Laschet, Institut National de la Santé et de la Recherche Médicale Unité 573, Centre Paul Broca, 2ter rue d'Alésia, F-75014 Paris, France. E-mail: jacques.laschet@broca.inserm.fr. D0I:10.1523/JNEUROSCI.0868-04.2004

Copyright $\odot 2004$ Society for Neuroscience $\quad 0270-6474 / 04 / 247614-09 \$ 15.00 / 0$
}

(TM1-4) (Unwin, 1993). A large intracellular domain (I2) located between TM3 and TM4 contains consensus phosphorylation sites for both Ser/Thr and Tyr protein kinases in several $\mathrm{GABA}_{\mathrm{A}} \mathrm{R}$ subunits (Moss and Smart, 1996). The $\beta$ and $\gamma$ subunits are phosporylated by type 2 calcium-calmodulin-dependent protein kinase (Machu et al., 1993; McDonald and Moss, 1994), cAMP-dependent protein kinase (PKA) (Kirkness et al., 1989; Browning et al., 1990; Moss et al., 1992a), $\mathrm{Ca}^{2+}$-phospholipiddependent protein kinase C (PKC) (Browning et al., 1990; Moss et al., 1992a; Krishek et al., 1994), cGMP-dependent protein kinase (McDonald and Moss, 1994; Robello et al., 1998), or protein-tyrosine kinase (Bureau and Laschet, 1995; Brandon et al., 2001). The effect of $\mathrm{GABA}_{\mathrm{A}} \mathrm{R}$ phosphorylation in cellular expression systems or in neuronal preparations are variable: phosphorylation of Ser/Thr residues by PKA or PKC results, in most cases, in a decrease of $\mathrm{GABA}_{\mathrm{A}} \mathrm{R}$ function (Moss et al., 1992b; Moss and Smart, 1996), although an increase in $\mathrm{GABA}_{\mathrm{A}}$-induced currents has also been reported (Lin et al., 1994; McDonald et al., 1998). Phosphorylation by PKA increases or decreases $\mathrm{GABA}_{\mathrm{A}}{ }^{-}$ mediated currents depending on the type of neuron and on the combination of $\beta$ isoform expressions (Nusser et al., 1999; Poisbeau et al., 1999). Phosphorylation of the Tyr residues either potentiates or maintains $\mathrm{GABA}_{\mathrm{A}}$-mediated inhibition (Moss et al., 1995; Wan et al., 1997; Huang and Dillon, 1998).

The state of phosphorylation of the receptor also depends on 
the rate of dephosphorylation, which has an equally dynamic and critical role in the modulation of synaptic transmission (Jones and Westbrook, 1997; Huang and Dillon, 1998).

In acutely dissociated neurons or in slices, maintenance of $\mathrm{GABA}_{\mathrm{A}} \mathrm{R}$ function requires favorable conditions for phosphorylation, by an unknown endogenous kinase requiring only the addition of ATP in the intracellular milieu (Stelzer et al., 1988; Chen et al., 1990; Krupp and Feltz, 1993; Gyenes et al., 1994; Kaneda et al., 1995). Using purified $\mathrm{GABA}_{\mathrm{A}} \mathrm{R}$ from bovine cerebral cortex, we and others have previously shown that this receptor-associated kinase activity is $\alpha 1$ specific (Sweetnam et al., 1988; Bureau and Laschet, 1995). Here, we report that, unexpectedly, the $\mathrm{GABA}_{\mathrm{A}} \mathrm{R}$ endogenous kinase is the glycolytic enzyme glyceraldehyde-3-phosphate dehydrogenase (GAPDH), providing the first example of a direct functional link between glycolysis and neurotransmission.

\section{Materials and Methods}

Receptor endogenous phosphorylation. Benzodiazepine affinity chromatography-purified $\mathrm{GABA}_{\mathrm{A}} \mathrm{Rs}$ from bovine cerebral cortex (Stauber et al., 1987; Bureau and Laschet, 1995) (0.5-1 mg protein $/ \mathrm{ml}$ ) were incubated with $0.33 \mu \mathrm{M}\left[\gamma_{-}{ }^{33} \mathrm{P}\right] \mathrm{ATP}, \mathrm{Mg}^{2+}, \mathrm{NADH}$, and ADP in HEPES-Tris buffer $(50 \mathrm{~mm}$ at $\mathrm{pH} 7.3)$ for $0-100 \mathrm{~min}$ at $30^{\circ} \mathrm{C}$. GAPDH (rabbit muscle; Boehringer Mannheim, Mannheim, Germany) was added in some experiments. Receptor phosphorylation was also studied in washed brain cell membranes (Stauber et al., 1987; Bureau and Laschet, 1995), with ${ }^{32} \mathrm{P}_{\mathrm{i}}$ added at micromolar concentrations to restrict labeling to $\mathrm{GABA}_{\mathrm{A}} \mathrm{R} \alpha 1$ subunit (Minier et al., 2000). The incubation time was $10 \mathrm{~min}$ at $30^{\circ} \mathrm{C}$, in the presence or absence of the required glycolytic intermediates [glyceraldehyde-3-phosphate (G3P), NAD ${ }^{+}, \mathrm{P}_{\mathrm{i}}$, $\mathrm{ADP}, \mathrm{Mg}^{2+}$ ], without addition of the glycolytic enzymes. Proteins were precipitated in a methanol-chloroform mixture and subjected to SDSPAGE. Radioactivity was counted using a PhosphorImager scanner (Storm 840; Molecular Dynamics, Sunnyvale, CA) after gel exposure on a storage $\mathrm{P}$-screen or by direct scanning with a $\beta$-Imager (Biospace Mesures, Paris, France).

Receptor immunoprecipitation. Purified $\mathrm{GABA}_{\mathrm{A}} \mathrm{R}(50 \mu \mathrm{l})$, labeled by endogenous phosphorylation, was incubated for $2 \mathrm{hr}$ at $4^{\circ} \mathrm{C}$ with varying dilutions of an anti- $\alpha 1$ antibody $(0.1 \mathrm{ml} / \mathrm{ml}$; clone bd24; Boehringer Mannheim) or an anti-GAPDH antibody $(4.9 \mathrm{mg} / \mathrm{ml}$; Chemicon, Temecula, CA) in a final volume of $200 \mu \mathrm{l}$ with phosphate buffer containing $0.1 \%$ Triton X-100. After the addition of $200 \mu \mathrm{l}$ of goat anti-mouse IgG conjugated to agarose with $1 \%$ bovine serum albumin, the samples were carefully shaken for $16 \mathrm{hr}$ at $4^{\circ} \mathrm{C}$. The immunosorbent was removed by centrifugation, and the supernatant and pellets were assayed individually. To further isolate the phosphorylated $\alpha 1$ receptor subunit from the autophosphorylated GAPDH, both immunoprecipitated by the antiGAPDH antibody, the proteins were separated by SDS-PAGE and analyzed by autoradiography as described above. A monoclonal antibody of the same isotype (mouse IgG2a toward Aspergillus niger glucose oxidase, an enzyme that is neither present nor inducible in mammalian tissues; Dako, Trappes, France) was used as a negative control.

Western blotting. Purified $\mathrm{GABA}_{\mathrm{A}}$ Rs were transferred from polyacrylamide gels to polyvinylidene difluoride membranes. After incubation with a blocking reagent, the preparation was incubated overnight with the anti-GAPDH, the anti- $\alpha 1$ (the same antibodies used for immunoprecipitation), or the negative control antibody in Tris buffer, $\mathrm{pH} \mathrm{7.2,} \mathrm{at} 4^{\circ} \mathrm{C}$. Immunostaining was performed using $0.25 \mathrm{U}$ of anti-mouse Ig-AP/ml buffer for $1 \mathrm{hr}$ at room temperature, followed by incubation of the samples for $20 \mathrm{~min}$ with $0.3 \mathrm{~mm}$ 4-nitroblue tetrazolium chloride/0.7 mM 5-bromo4-chloro-3-indolyl phosphate in $0.1 \mathrm{~m}$ Tris-chloride buffer, $\mathrm{pH}$ 7.2.

Fusion protein constructs. Plasmid constructs were obtained as follows. The second intracellular loop region $\mathrm{I} 2 \alpha 1$ (aa 334-420) of the $\mathrm{GABA}_{\mathrm{A}} \mathrm{R}$ $\alpha 1$ subunit was amplified by reverse transcription-PCR on mRNA extract from rat brain cortex with the primers $5^{\prime}$-CGGAATTCAACTATTTCACCAAGAGAGG-3' and 5'-CGCTCGAGTCATCGGTCGATTTTGCTGACGCTG-3', then in-frame inserted in the plasmid pcDNA3.1HisC
(Invitrogen, San Diego, CA), between the polylinker EcoR1 and XhoI sites. Mutagenesis of I $2 \alpha 1$ (T337A and S416G double mutant) was performed by PCR on the I $2 \alpha 1$ recombinant plasmid with the primers $5^{\prime}$ CGGAATTCAACTATTTCGCCAAGAGAGG-3' and 5'-CGCTCGAGTCATCGGTCGATTTTGCCGACGCTG-3', then reinserted in the same vector. Both wild-type (WTI $2 \alpha 1$ ) and mutant (mutI $2 \alpha 1$ ) constructs were separately PCR amplified by the primers $5^{\prime}$-CCGCTCGAGCGGAAGCTTACCATGGGG-3' and 5'-GGAATTCCGAGTCCTCGGTCGATTTTGC-3', and the resulting 400 bp cDNAs were in-frame subcloned in a second vector, pEYFP-N1 (BD Biosciences Clontech, Erembodegem, Belgium), between XhoI and EcoR1. For the control construct [yellow fluorescent protein (YFP)], the WTI $2 \alpha 1$ recombinant pEYFP-N1 was digested by EcoR 1 to release the I $2 \alpha 1$ sequence and ligated after Klenow filling, such that the I $2 \alpha 1$ insert is replaced by a single Leu codon. All constructions were checked by nucleotide sequencing.

COS7 cells were cultured in DMEM (Life Technologies, Paisley, UK) supplemented with $10 \%$ fetal calf serum and $100 \mu \mathrm{g} / \mathrm{ml}$ penicillin-streptomycin in a humidified atmosphere of $5 \% \mathrm{CO}_{2} / 95 \%$ air and transiently transfected by using Superfect (Qiagen, Courtaboeuf, France) and $10 \mu \mathrm{g}$ of pEYFP-N1-WTI2 $\alpha 1$, pEYFP-N1-mutI2 $\alpha 1$, and pEYFP-N1-control, respectively. Fusion protein expressions were assessed by Western blotting with either Xpress (diluted 1:5000; Invitrogen, Leek, The Netherlands) or poly-histidine (diluted 1:3000; clone HIS-1; Sigma, Saint Quentin Fallavier, France) primary antibodies and goat (heavy and light chain) anti-mouse IgG-HRP secondary antibody (diluted 1:1000; Bio-Rad, Ivry-sur-Seine, France) and detected by ECL + Plus luminescence (Amersham Biosciences, Buckinghamshire, UK). Recombinant proteins were purified from the cytosolic extracts on a nickelchelating HisTrap column (Amersham Biosciences, Uppsala, Sweden) and followed-up by fluorescence.

The direct phosphorylation assay with the fusion proteins was the same procedure as for the receptor endogenous phosphorylation, except for the addition of GAPDH. To allow protein-protein interaction, each construct was codialyzed with GAPDH $(100 \mu \mathrm{g} / \mathrm{ml})$. The amounts of the three constructs were equalized according to their fluorescence.

Double fluorescence immunocytochemistry. Primary cultures of hippocampal neurons were prepared from embryonic day 18 rat embryos (Fuhrmann et al., 2002). At $12 \mathrm{~d}$ in vitro, cells were fixed with $4 \%$ paraformaldehyde in phosphate buffer $(0.1 \mathrm{M}, \mathrm{pH} 7.4)$ containing $4 \%$ sucrose at room temperature for $15 \mathrm{~min}$, rinsed in PBS, and permeabilized with $0.25 \%$ Triton X-100 in 0.02 M PBS containing $0.2 \%$ gelatin and $10 \%$ normal goat serum for $30 \mathrm{~min}$. Primary antibodies were simultaneously incubated overnight at $+4^{\circ} \mathrm{C}$. GAPDH mouse monoclonal antibody (Chemicon) was used at $10 \mu \mathrm{g} / \mathrm{ml}$. The antibody against the $\alpha 1$ subunit of the rat $\mathrm{GABA}_{\mathrm{A}} \mathrm{R}$ (a gift from Prof. W. Sieghart, Brain Research Institute, Vienna, Austria) (Sperk et al., 1997) was used at $0.5 \mu \mathrm{g} / \mathrm{ml}$. After rinsing, cells were incubated with biotinylated anti-rabbit Ig (concentrated rabbit link; BioGenex, San Ramon, CA) at a 1:100 dilution for 30 $\mathrm{min}$ at room temperature, rinsed again, and incubated in a mixture of Cy3-conjugated streptavidin ( $1 \mu \mathrm{g} / \mathrm{ml}$; Jackson ImmunoResearch, West Grove, PA) and Alexa Fluor 488 goat anti-mouse (1:100; Molecular Probes Europe, Leiden, The Netherlands) for $1 \mathrm{hr}$ at room temperature. Coverslips were mounted with Vectashield (Vector Laboratories, Burlingame, CA). In the controls in which the primary antibodies were omitted, no immunostaining could be observed. Immunostaining was analyzed using a Leica TCS-SP2 confocal laser-scanning microscope. All pictures are single confocal sections averaged four to six times to reduce noise.

Electrophysiology. Adult Sprague Dawley rats (35-40 d of age) were anesthetized with ether and killed by decapitation. The brains were removed quickly and placed in cold artificial CSF. Cortical neurons were acutely dissociated from $400 \mu \mathrm{m}$ slices by incubation in protease-XXIII ( $3 \mathrm{mg} / \mathrm{ml}$; Sigma) at $32^{\circ} \mathrm{C}$, followed by mechanical dissociation. After washing, the cells were transferred in a solution containing (in $\mathrm{mM}$ ) 135 $\mathrm{NaCl}, 3 \mathrm{KCl}, 2 \mathrm{CaCl}_{2}, 10$ HEPES, $1 \mathrm{MgCl}_{2}, 7 \mathrm{TEA}-\mathrm{Cl}, 10$ D-glucose, and 1 $\mu \mathrm{M}$ TTX, $\mathrm{pH}$ 7.4. Pyramidal neurons were recorded using borosilicate pipettes $(4-5 \mathrm{M} \Omega$ ) filled with a solution containing (in $\mathrm{mm}$ ) $130 \mathrm{CsF}, 10$ $\mathrm{CsCl}, 4 \mathrm{NaCl}, 0.5 \mathrm{CaCl}_{2}, 10 \mathrm{HEPES}, 5 \mathrm{EGTA}$, and $7 \mathrm{Mg}$-ATP. Additions were made to this standard pipette milieu for specific experiments: GAPDH $(1 \mu \mathrm{g} / \mathrm{ml}), \mathrm{NAD}^{+}(5$ or $50 \mu \mathrm{M}), \mathrm{NADH}(5 \mu \mathrm{M}), \mathrm{G} 3 \mathrm{P}(500 \mu \mathrm{M})$, 


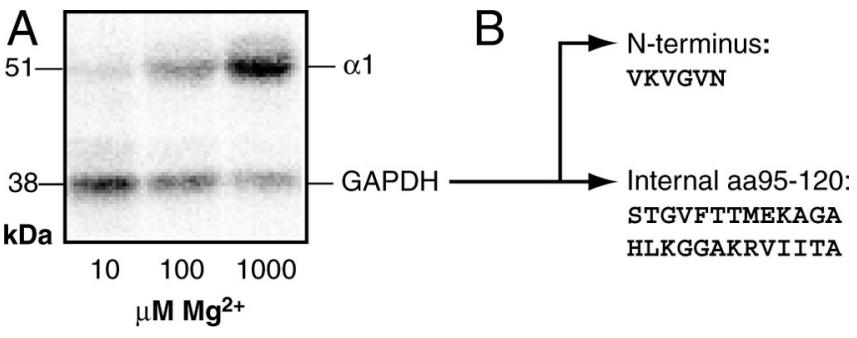

Figure 1. Endogenous phosphorylation of the $\alpha 1$ subunit of purified $G A B A_{A} R$ and identification of the kinase candidate. $A$, Gel autoradiography showing a phosphorylation cascade of copurified $38 \mathrm{kDa}$ protein to the $\alpha 1$ subunit (51 kDa) after a $30 \mathrm{~min}$ incubation in the presence of ${ }^{33}$ P-ATP $(0.33 \mu \mathrm{M})$ and increasing $\left[\mathrm{Mg}^{2+}\right]$. B, Microsequencing of the $38 \mathrm{kDa}$ protein revealing two sequences of bovine GAPDH.

ortho-vanadate $(100 \mu \mathrm{M})$, or okadaic acid $(10 \mu \mathrm{M})$. The seals were made with these compounds in the pipette. In other experiments, iodoacetamide $(500 \mu \mathrm{M})$ was added to the bath between recording times $t=6 \mathrm{~min}$ and $t=9 \mathrm{~min}$ and maintained until the end of the experiment. Wholecell peak currents induced by GABA (100 $\mu \mathrm{M}$; pressure ejections or fast applications, $1 \mathrm{sec}$ pulse every $3 \mathrm{~min}$ ) were measured for each application and normalized to the maximal response $(t=0 \mathrm{~min})$. This maximal response was observed within $0-6 \mathrm{~min}$ after patching because, in some cases, there was an initial run-up. Neurons were held at $-80 \mathrm{mV}$ such that $\mathrm{GABA}$ evoked inward currents $\left(\mathrm{Cl}^{-}\right.$equilibrium potential close to $-40 \mathrm{mV}$ ). In control experiments, $\mathrm{CsF}$ was replaced by $\mathrm{CsCl}$ : the holding potential was then $-40 \mathrm{mV}\left(\mathrm{Cl}^{-}\right.$equilibrium potential close to $\left.0 \mathrm{mV}\right)$. The statistical significance was assessed using a one-way ANOVA and a two-way ANOVA for repeated measures, followed by Dunnett's post hoc analysis (one-tailed distribution).

\section{Results}

\section{GAPDH is the $\mathrm{GABA}_{\mathrm{A}} \mathrm{R}$ endogenous kinase}

Preparations of $\mathrm{GABA}_{\mathrm{A}} \mathrm{R}$ purified from bovine cerebral cortex consistently included an additional copurified $38 \mathrm{kDa}$ polypeptide (P38) (Figs. $1 \mathrm{~A}, 2 \mathrm{~A})$. At physiological $\left[\mathrm{Mg}^{2+}\right](1 \mathrm{~mm})$ and with $\left[{ }^{33} \mathrm{P}\right] \mathrm{ATP}$ (without the addition of any protein kinase or of their activators), $\mathrm{GABA}_{\mathrm{A}} \mathrm{R}$ phosphorylation occurred at the receptor $\alpha 1$ subunit only ( $51 \mathrm{kDa})$, as shown by Western blotting (Fig. 2 A). These data confirms previous studies (Sweetnam et al., 1988; Bureau and Laschet, 1995; Minier et al., 2000). At $10 \mathrm{~mm}$ $\left[\mathrm{Mg}^{2+}\right]$ or greater, phosphorylation appears also in subunits of higher molecular weight ( $\sim 53-55 \mathrm{kDa}$; data not shown). At 10 $\mu \mathrm{M}\left[\mathrm{Mg}^{2+}\right]$, a marked labeling of P38 was still observed, whereas that of the $\alpha 1$ subunit was very faint; at $100-1000 \mu \mathrm{M}\left[\mathrm{Mg}^{2+}\right]$, the ${ }^{33} \mathrm{P}$-labeling of the $\alpha 1$ subunit increased, whereas that of P38 decreased (Fig. 1A). Kinetic studies at $1 \mathrm{~mm}\left[\mathrm{Mg}^{2+}\right]$ suggested that phosphorylation of P38 occurred before any significant incorporation of ${ }^{33} \mathrm{P}$-phosphate at the $\alpha 1$ subunit (data not shown). We made the assumption that P38 is the receptor $\alpha 1$ subunit endogenous protein kinase.

The P38 copurifying with $\mathrm{GABA}_{\mathrm{A}} \mathrm{R}$ was separated and microsequenced (Fig. $1 B$ ). The first six $\mathrm{N}$-terminal amino acids were identical to the $\mathrm{N}$ terminus amino acids of bovine (aa 1-6) and human (aa 3-8) GAPDH (Kulbe et al., 1975; Ercolani et al., 1988), a key glycolytic enzyme. To rule out any possible comigration of another N-blocked protein, an internal fragment of P38 was purified after controlled proteolysis by endoproteinase Lys- $\mathrm{C}$ and sequenced. The first 26 amino acids obtained corresponded to the aa 95-120 of bovine GAPDH (except for a S119T substitution) and were highly homologous to the aa 97-122 of the human GAPDH. Moreover, an anti-GAPDH monoclonal antibody recognized the copurified P38 band without cross-reacting with any other protein of the purified receptor preparation (Fig. 2A).
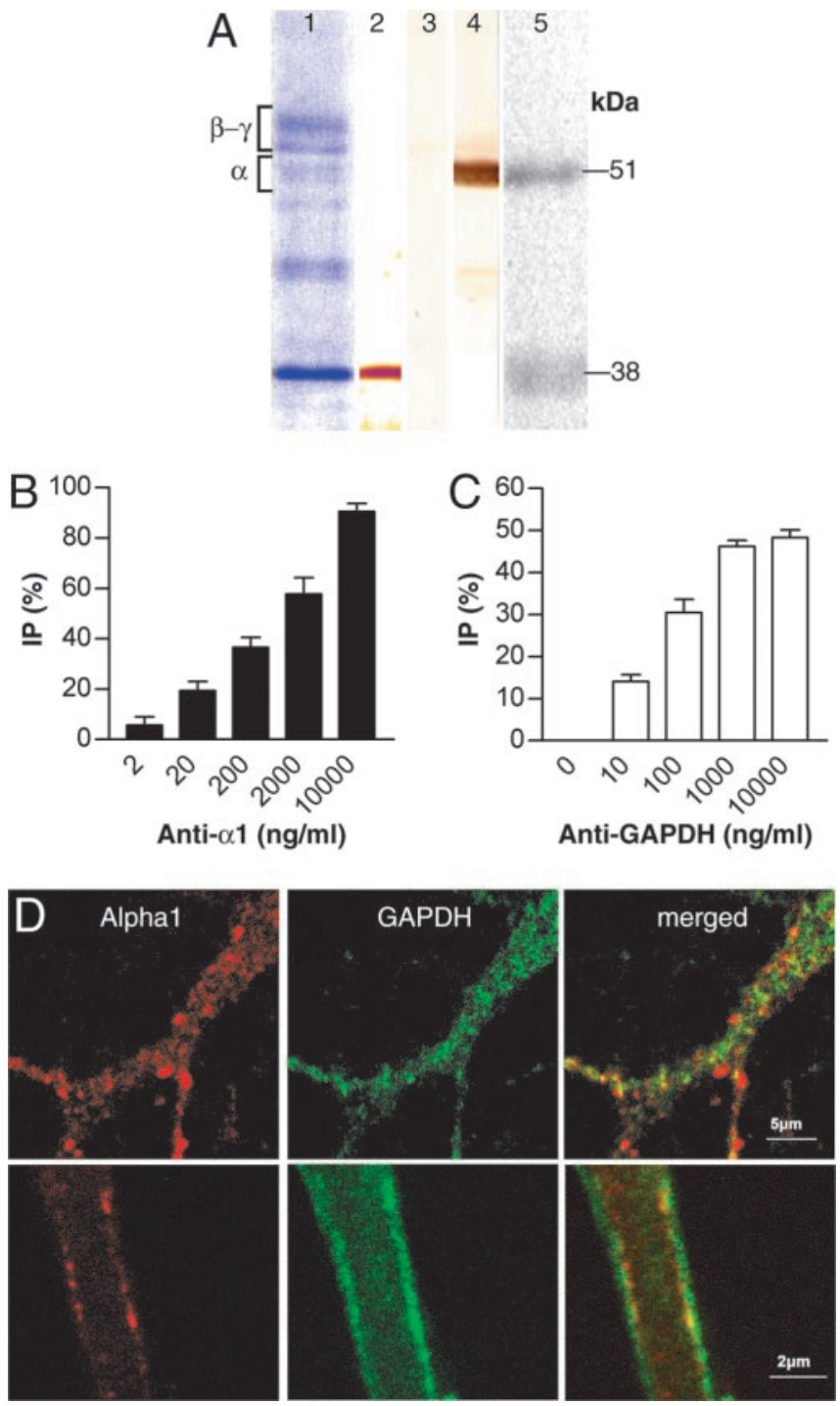

Figure 2. Molecular association between $G A P D H$ and the $G_{A B A} R \alpha 1$ subunit. $A, G A B A_{A} R$ purified preparations from bovine brain cortex were separated and stained showing the main subunits (lane 1), probed with anti-GAPDH (lane 2), negative control (lane3), or anti- $\alpha 1$ (lane 4) monoclonal antibodies at $10 \mu \mathrm{g} / \mathrm{ml}$, or ${ }^{33} \mathrm{P}$-autoradiographed after endogenous phosphorylation (lane 5). $B$, Immunoprecipitation of ${ }^{33}$ P-labeled purified $G A B A_{A} R$ receptor by an anti- $\alpha 1$ antibody at varying concentrations. Error bars are SEM $(n=3)$. C, Immunoprecipitation of ${ }^{33}$ P-labeled purified $G A B A_{A} R \alpha 1$ subunits by an anti-GAPDH antibody at varying concentrations; measurements on isolated $\alpha 1$ subunit were performed by autoradiography after protein gel electrophoresis. Error bars are SEM $(n=3)$. D, Subcellular colocalization of the $G_{A B A} R \alpha 1$ subunit (red) with GAPDH (green) at the cell membrane of rat hippocampal neurons in primary cultures at day 12 in vitro, observed by confocal microscopy. The top view shows a neuron, and the bottom view shows a dendrite of another neuron at higher magnification.

Thus, the P38 receptor-associated protein corresponded to GAPDH.

It is known that GAPDH is autophosphorylated in the sole presence of Mg-ATP and transfers its incorporated phosphate to unknown target proteins (Kawamoto and Caswell, 1986). Thus, it is likely that the ${ }^{33} \mathrm{P}$-labeling of the $38 \mathrm{kDa}$ protein now identified as being GAPDH is attributable to autophosphorylation. The observation that increasing $\left[\mathrm{Mg}^{2+}\right]$ produced opposite effects on the phosphorylation of GAPDH (decreased) and on that of $\alpha 1$ subunit (increased) (Fig. $1 A$ ) indicates a phospho-transfer from the autophosphorylated GAPDH to the $\alpha 1$ subunit. 
$\mathrm{GABA}_{\mathrm{A}} \mathrm{R}-\mathrm{GAPDH}$ association

Nearly $90 \%$ of the ${ }^{33}$ P-labeled $\mathrm{GABA}_{\mathrm{A}} \mathrm{R}$ was immunoprecipitated by the $\alpha 1$-specific bd24 monoclonal antibody at $10 \mu \mathrm{g} / \mathrm{ml}$ (Fig. 2B); in control experiments performed with an irrelevant monoclonal antibody (see Materials and Methods) of the same isotype (IgG2a) at the same dilutions, no radioactivity was immunoprecipitated (data not shown). The anti-GAPDH monoclonal antibody immunoprecipitated purified $\mathrm{GABA}_{\mathrm{A}} \mathrm{R}$, phosphorylated with $\left[{ }^{33} \mathrm{P}\right] \mathrm{ATP}$ and $1 \mathrm{~mm} \mathrm{Mg}{ }^{2+}$. To exclude from the total ${ }^{33} \mathrm{P}$ immunoprecipitated by the anti-GAPDH antibody the part attributable to GAPDH autophosphorylation, the $\alpha 1$ subunit was further isolated by protein gel electrophoresis, and autoradiographic counting was restricted to the $51 \mathrm{kDa}$ band that is recognized by the anti- $\alpha 1$ antibody. At anti-GAPDH antibody concentrations of $1-10 \mu \mathrm{g} / \mathrm{ml}$, half of the ${ }^{33} \mathrm{P}$-labeled $\alpha 1$ subunit was adsorbed (Fig. 2C); in control experiments with the irrelevant monoclonal antidody, no immunoprecipitation was achieved (data not shown). These results indicate that at least $50 \%$ of the $\alpha 1$ subunits were bound either directly or indirectly to GAPDH. This interaction between $\alpha 1$ and GAPDH can be considered as specific because GAPDH remained in high amounts even after stringent washing during receptor preparation (Fig. $2 A$, lane 1). Nevertheless, a partial loss of GAPDH during the procedure cannot be ruled out.

A close association between GAPDH and the $\mathrm{GABA}_{\mathrm{A}} \mathrm{R} \alpha 1$ subunit implies their colocalization at the neuronal plasma membrane. Double fluorescence immunocytochemistry with confocal microscopy was performed on primary cultures of rat hippocampal neurons. On day 12 in vitro, $\alpha 1$ subunit immunoreactivity formed bright puncta (red) along the surface membrane of somata and dendrites (Fig. 2D) of most neurons (16 of 28). Whereas a light and sparse cytoplasmic GAPDH immunostaining (green) was visible in the cell bodies and dendrites of all neurons $(n=75)$, conspicuous labeling was concentrated at the cell membrane, giving a somewhat discontinuous appearance (Fig. 2D). On superimposed images, all immunoreactive dots reveal the receptor $\alpha 1$ subunit colocalized with the GAPDHimmunoreactive fluorescence at or near the neuronal membrane (Fig. 2D). In washed cortical membranes, we measured a GAPDH activity of $\sim 10 \mu$ katal per milligram of protein.

\section{Direct $\alpha 1{ }^{337} \mathrm{Thr} /{ }^{416}$ Ser-phosphorylation by GAPDH}

The phosphorylation cascade between GAPDH and the $\alpha 1$ subunit may be indirect and require one or several intermediates. To rule out this possibility, we tested the direct phosphorylation by GAPDH on purified fusion proteins. The long intracellular domain I2 (also called M3-M4) of the rat $\alpha 1$ subunit (I2 $\alpha 1$ ), a candidate site for phosphorylation, was expressed in COS7 cells. The constructs include I $2 \alpha 1$, an N-leader tagged for immunodetection and purification, and a YFP at the C terminus for rapid expression detection. No phosphorylation occurred after incubation of the purified fusion protein with $\left[{ }^{33} \mathrm{P}\right] \mathrm{Mg}$-ATP (data not shown). When highly purified GAPDH was added, it autophosphorylated (GAPDH labeling) (Fig. 3C, $38 \mathrm{kDa}$ band), and the fusion protein containing I $2 \alpha 1$ was also phosphorylated (Fig. 3C, $36 \mathrm{kDa}$ band). A control construct ( $25 \mathrm{kDa}$ ) containing only the tags and YFP was not phosphorylated (Fig. 3C-E). This demonstrates that GAPDH directly phosphorylates $\mathrm{I} 2 \alpha 1$.

Numerous Thr, Ser, and Tyr phosphorylable residues are present in $\mathrm{I} 2 \alpha 1$ (Fig. $3 B$ ), but it is known that endogenous phosphorylation involves only Ser and Thr residues on $\alpha 1$ and possibly $\alpha 2$ subunits but not Tyr on these subunits (Bureau and Laschet, 1995). To determine any possible consensus sites for this
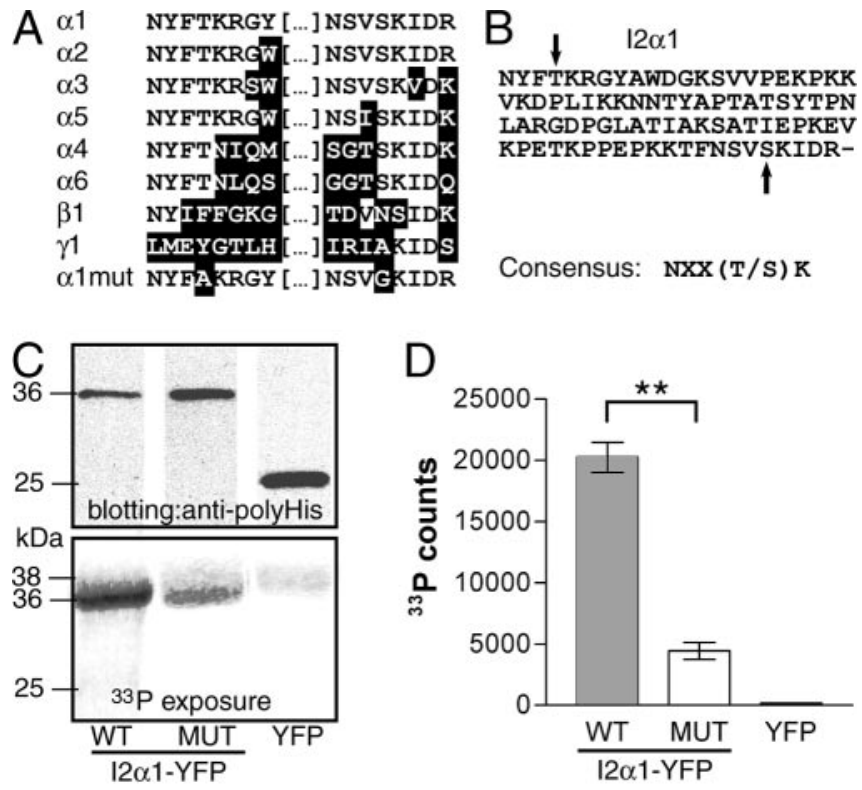

Consensus: $\operatorname{NXX}(\mathrm{T} / \mathrm{S}) \mathrm{K}$

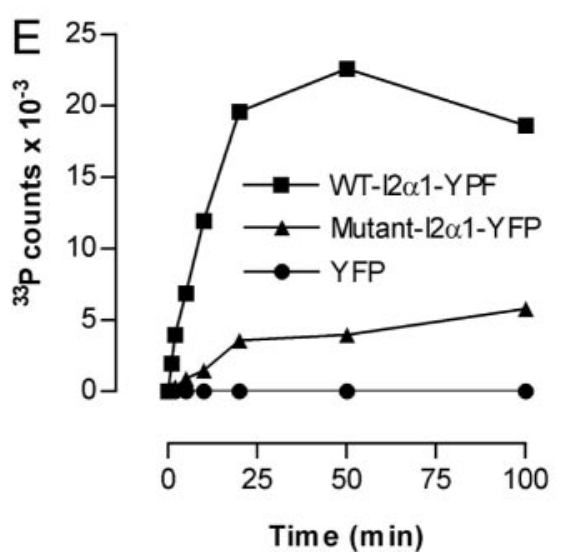

Figure 3. Direct phosphorylation of the recombinant long intracellular domain of the $G A B A_{A}$ $\alpha$ subunit at identified Ser and Thr residues. $A$, Conserved end sequences of the long intracellular domain of mammalian $\mathrm{GABA}_{\mathrm{A}} \mathrm{R}$ in several $\alpha$ subunits, but not in $\beta$ - $\gamma$ subunits. Sitedirected mutations of ${ }^{337} \mathrm{Thr}$ and ${ }^{416} \mathrm{Ser}$ in the mutated $\alpha 1$ subunit construct ( $\left.\alpha 1 \mathrm{mut}\right)$. Amino acids diverging from the $\alpha 1$ subunit are boxed. $B$, The sequence of the long intracellular domain of the $\alpha 1$ subunit contains numerous Ser and Thr residues. The arrows indicate mutation sites. The consensus sequence of the presumed phosphorylation sites is shown. C, Purified wild-type I2 $\alpha 1$-YFP (WT), Ser/Thr double mutant I2 $\alpha 1$-YFP (MUT), or control (YFP) constructs were phosphorylated directly by GAPDH in the presence of $\mathrm{Mg}^{2+}$ and ${ }^{33}$ P-ATP, separated, and probed with an anti-polyHis antibody (top) or ${ }^{33} \mathrm{P}$-autoradiographed (bottom). D, Counting of the ${ }^{33} \mathrm{P}$ incorporation by GAPDH of wild-type I2 $\alpha 1$-YFP (WT-12 $\alpha 1$-YFP), Ser/Thr double mutant (MUT$12 \alpha 1$-YFP), or control (YFP). Error bars are SEM $(n=3)$. The mutation effect on phosphorylation (22\% of the wild type) is significant ( $p<0.01$; paired Student's $t$ test). E, Representative kinetics of the phosphorylation by GAPDH of the constructs mentioned in $C$ and $D$.

phosphorylation, we compared the rat I $2 \alpha 1$ sequence (which is identical to the human, bovine, and mouse sequences) with different $\mathrm{GABA}_{\mathrm{A}} \mathrm{R}$ subunit sequences. We found at both ends of I $2 \alpha 1$, two $\alpha(1-3,5)$ subunit-specific highly conserved regions centered on ${ }^{337} \mathrm{Thr}$ and ${ }^{416} \mathrm{Ser}$, with a minimum consensus sequence $[\mathrm{NXX}(\mathrm{T} / \mathrm{S}) \mathrm{K}]$ (Fig. $3 A, B)$. Site-directed mutagenesis was performed on the recombinant protein such that the double mutant (T337A and S416G) presented nonphosphorylable residues at both presumed sites. The GAPDH phosphorylation assayed at the plateau value (incubation time longer than $20 \mathrm{~min}$ ) on the modified protein $\left(36 \mathrm{kDa}\right.$ ) showed that $78 \%$ of the ${ }^{33} \mathrm{P}$ incorporation observed on the wild type disappeared (Fig. $3 C-E$ ). The 
remaining labeling (22\%) may be attributable to less specific phosphorylable residues that we did not attempt to identify. Therefore, ${ }^{337} \mathrm{Thr}$ and ${ }^{416}$ Ser sites account for most of the I $2 \alpha 1$ phosphorylation by GAPDH in vitro.

\section{Factors influencing endogenous kinase}

At $100 \mu \mathrm{M}\left[\mathrm{Mg}^{2+}\right]$, phosphorylation of the $\mathrm{GABA}_{\mathrm{A}} \mathrm{R} \alpha 1$ subunit was maximally activated twofold by $1-10 \mu \mathrm{g} / \mathrm{ml}$ of added exogenous GAPDH, with an $\mathrm{EC}_{50}$ value of $\sim 50 \mathrm{ng} / \mathrm{ml}$ ( $1.3 \mathrm{nM}$; data not shown; $n=3$ ). The phospho-GAPDH was stable at $\mathrm{pH} 4$ but hydrolyzed after a long exposure to neutral and alkaline $\mathrm{pH}$ (Kawamoto and Caswell, 1986). For this reason, autophosphorylation of GAPDH was not always apparent in our experiments after gel electrophoresis: labeling was constantly observed only when GAPDH was added at high concentrations.

The reduced GAPDH coenzyme NADH facilitates phosphate transfer from phospho-GAPDH to target proteins (Kawamoto and Caswell, 1986). The transfer of a phosphate group from the phospho-enzyme to the $\alpha 1$ substrate did not require a coenzyme (other than $\mathrm{Mg}^{2+}$ ), even if it was enhanced by $\mathrm{NADH}(+33 \%$ at $1 \mu \mathrm{M}$; data not shown; $n=3$ ), most likely through its action on endogenous GAPDH. This effect was not related to the glycolytic activity of GAPDH because no glycolytic substrate was added. Furthermore, NADH is the reduced cofactor of GAPDH and thus opposes glycolytic ATP synthesis. Our results therefore suggest an allosteric interaction between the coenzyme and the kinase catalytic sites. In contrast, the addition of ADP decreased $\alpha 1$ endogenous phosphorylation $\left(\mathrm{IC}_{50}\right.$ value, $2 \mu \mathrm{M}$; data not shown; $n=3$ ), perhaps as a result of a thermodynamic effect because ADP is produced during GAPDH autophosphorylation. Autophosphorylation of GAPDH does not require a coenzyme; it requires only $\mathrm{Mg}^{2+}$-ATP. The catalytic Cys residue related to the dehydrogenase action of GAPDH does not play a role in its phosphotransferase activity because the sulfhydryl alkylating agent iodoacetamide, a GAPDH inhibitor, did not inhibit phosphorylation of the $\mathrm{GABA}_{\mathrm{A}} \mathrm{R} \alpha 1$ subunit (data not shown; $n=3$ ). These results show that, in the presence of $\mathrm{Mg}$-ATP, phosphorylation of the $\mathrm{GABA}_{\mathrm{A}} \mathrm{R} \alpha 1$ subunit by GAPDH did not directly require the reactions involved in the dehydrogenase activity.

\section{Glycolysis-dependent membrane receptor phosphorylation}

We have previously shown that $\mathrm{GABA}_{\mathrm{A}} \mathrm{R}$ endogenous phosphorylation in washed membrane preparations is more efficient than that of the purified receptors, and that ${ }^{33} \mathrm{P}$ incorporation from ATP at micromolar concentrations is highly specific for the $\alpha 1$ subunit (Minier et al., 2000). It may be asked whether the membrane preparation retains the capacity to generate ATP from the glycolytic precursors when no exogenous enzyme is added. When the membranes were incubated with the specific GAPDH substrate G3P, together with the other ingredients necessary for glycolysis $\left(\mathrm{NAD}^{+}, \mathrm{ADP}, \mathrm{Mg}^{2+},{ }^{32} \mathrm{P}_{\mathrm{i}}\right.$ ), the $\alpha 1$ subunits were indeed labeled (Fig. 4A). In this condition, the only labeled precursor was the $\left[{ }^{32} \mathrm{P}\right]$-orthophosphate (no added ATP). Without G3P, the $\alpha 1$ subunit was not phosphorylated. Similarly, $\alpha 1$ phosphorylation did not occur when one of the other intermediates $\left(\mathrm{NAD}^{+}, \mathrm{ADP}, \mathrm{Mg}^{2+},{ }^{32} \mathrm{P}_{\mathrm{i}}\right)$ was omitted. Decreasing ADP concentration from 100 to $10 \mu \mathrm{M}$ enhanced labeling, thus reducing its inhibitory effect. The addition of exogenous cold ATP decreased labeling by isotopic dilution, thus demonstrating a production of $\left[{ }^{32} \mathrm{P}\right] \mathrm{ATP}$ at the membrane and its direct use for $\mathrm{GABA}_{\mathrm{A}} \mathrm{R}$ endogenous phosphorylation (Fig. $4 \mathrm{~B}$ ). From these data, it is also clear that ambient cold ATP can compete for $\alpha 1$
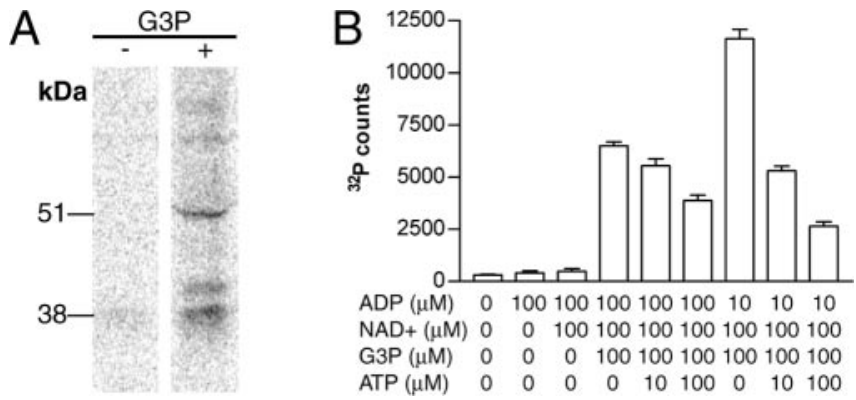

Figure 4. Involvement of membrane-associated glycolysis in the $G_{A B A} R$ phosphorylation. Local glycolytic ATP production was used for endogenous $\alpha 1$ phosphorylation in bovine cortical washed membranes. $A$, Autoradiograph of washed membranes incubated without any exogenous enzyme or activator, in the presence of $\mathrm{ADP}(10 \mu \mathrm{M}), \mathrm{NAD}^{+}(100 \mu \mathrm{M}), \mathrm{Mg}^{2+}(1 \mathrm{mM})$, and ${ }^{32} \mathrm{P}_{\mathrm{i}}(0.33 \mu \mathrm{M})$, without or with the specific GAPDH substrate $\mathrm{G} 3 \mathrm{P}(100 \mu \mathrm{M})$. Bands at 51 and 38 $\mathrm{kDa}$ are ${ }^{32} \mathrm{P}$-labeled $\alpha 1$ subunit and GAPDH, respectively. $B$, Effects of exogenous factors on phosphorylation of the $\alpha 1$ subunit, as expressed as counts in the $51 \mathrm{kDa}$ band, in the presence of $\mathrm{Mg}^{2+}(1 \mathrm{mM})$ and ${ }^{32} \mathrm{P}_{\mathrm{i}}(0.33 \mu \mathrm{M})$ of washed membranes. Error bars are SEM $(n=3)$.
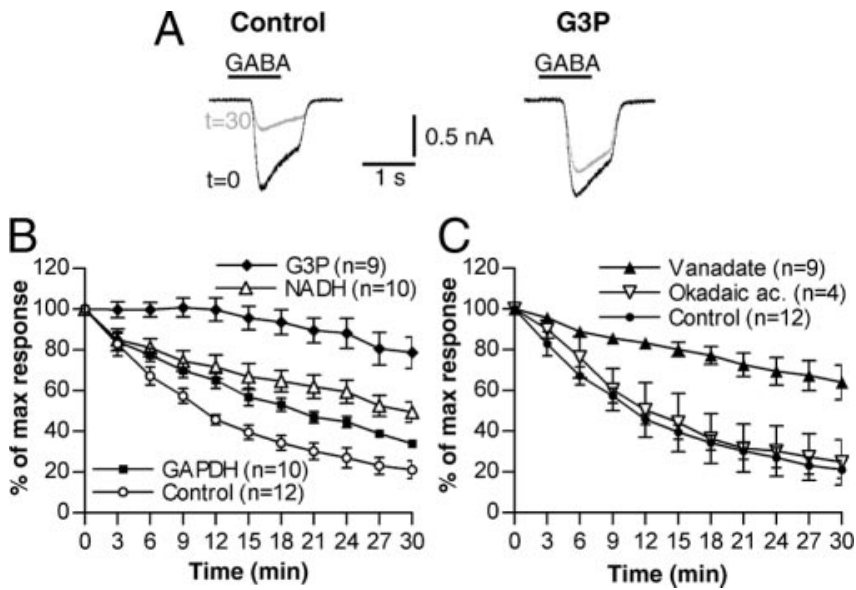

Figure 5. Glycolysis dependence of the functional maintenance of $G A B A_{A}$ currents. $A$, Superimposed whole-cell current traces induced by GABA (100 $\mu \mathrm{m})$ applied to acutely dissociated rat neocortical neurons at $t=0 \mathrm{~min}$ (black) and at $t=30 \mathrm{~min}$ (gray). Rundown of the responses was markedly decreased when G3P was added to the pipette milieu. $B$, Time course of normalized peak currents to GABA applied every 3 min during $30 \mathrm{~min}$ (holding potential, $-80 \mathrm{mV}$ ). The addition of GAPDH $(1 \mu \mathrm{g} / \mathrm{ml}), \mathrm{NADH}(5 \mu \mathrm{m})$, or G3P $(500 \mu \mathrm{m})$ to the pipette milieu reduced the rundown of responses ( $p=0.012, p<0.001$, and $p<0.001$ for GAPDH, NADH, and G3P, respectively; 2-way ANOVA with Dunnett's post hoc test). Error bars are SEM, and $n$ is the number of cells recorded. $C$, The phosphatase inhibitor orthovanadate $(100 \mu \mathrm{m})$ added in the pipette mostly prevented rundown ( $p<0.005$ ), whereas okadaic acid $(10 \mu \mathrm{m})$ had no effect.

phosphorylation and exchange with the glycolytic $\left[{ }^{32} \mathrm{P}\right] \mathrm{ATP}$ produced at the membrane.

\section{Function of GAPDH-dependent phosphorylation}

In whole-cell recordings from dissociated neurons, the amplitude of $\mathrm{GABA}_{\mathrm{A}} \mathrm{R}$-mediated responses decreases with successive applications of GABA. This rundown involves a phosphorylationdephosphorylation process (Stelzer et al., 1988; Chen et al., 1990; Gyenes et al., 1994; Kaneda et al., 1995). Using whole-cell recordings, the currents elicited by GABA $(100 \mu \mathrm{M})$ were measured in neurons acutely dissociated from rat cortex (Fig. 5A). Magnesium ions activate both phosphorylation and dephosphorylation of the receptor (see below), and a concentration of $7 \mathrm{mM} \mathrm{Mg-ATP}$ was chosen to provide a robust and reproducible rundown of $\mathrm{GABA}_{\mathrm{A}}$ responses. Lowering the $[\mathrm{Mg}$-ATP] led to a more rapid rundown, and changing the $\left[\mathrm{Mg}^{2+}\right] /[\mathrm{ATP}]$ molar ratio also influenced rundown (data not shown). When Mg-ATP was omit- 

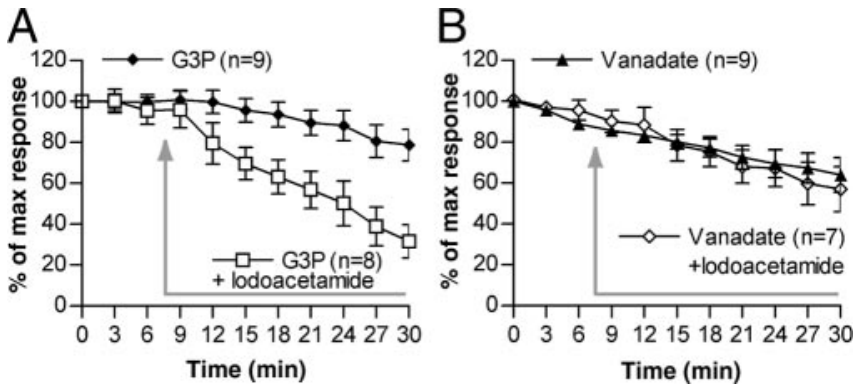

Figure 6. Functional effect of GAPDH inactivation. lodoacetamide, an inhibitor of the dehydrogenase activity of GAPDH ( $500 \mu \mathrm{m}$ ), was added to the bath between $t=6 \mathrm{~min}$ and $t=9$ min and maintained during the rest of the recordings (arrows). $A$, lodoacetamide abolished the preventive effect of G3P (500 $\mu \mathrm{m}$ ) on rundown (7 mM ATP in the pipette; $p<0.001$; 2-way ANOVA with Dunnett's post hoc test). Error bars are SEM, and $n$ is the number of cells recorded. $B$, In the presence of phosphatase inibitor vanadate (100 $\mu \mathrm{m})$, iodoacetamide could no longer accelerate the rundown of $G A B A_{A}$ responses.

ted from the pipette milieu, GABA responses declined rapidly and were nearly abolished within 9-12 min after patching (data not shown).

With $7 \mathrm{~mm}$ Mg-ATP in the intracellular medium, the response declined steadily to $21 \%$ of the maximal response after $30 \mathrm{~min}$ (Fig. $5 B$ ). With the addition of GAPDH in the pipette milieu (1 $\mu \mathrm{g} / \mathrm{ml}$ ), the $\mathrm{GABA}_{\mathrm{A}}$ response was reduced to only $34 \%$ of the maximum at $30 \mathrm{~min}$ (Fig. $5 \mathrm{~B}$ ). The response was even more preserved with the addition of G3P $(500 \mu \mathrm{M})$, the glycolytic substrate of GAPDH, at $79 \%$ of the maximum at $30 \mathrm{~min}$. Because this effect was obtained with $7 \mathrm{~mm} \mathrm{Mg-ATP}$ in the pipette, it shows that prevention of rundown is mainly dependent on glycolytic, but not ambient, ATP. NADH, which increased the kinase activity of GAPDH, also markedly preserved the responses ( $53 \%$ at $30 \mathrm{~min}$ ) when added at $5 \mu \mathrm{M}$ to the intracellular solution (Fig. $5 B$ ). NAD ${ }^{+}$ ( 5 or $50 \mu \mathrm{M}$ ) was much less effective $(25 \%$ at $30 \mathrm{~min}$; data not shown). From the one-way ANOVA with Dunnett's post hoc tests, the difference of response amplitudes compared with the control was significant $(p<0.01)$ at and after $t=6 \mathrm{~min}$ for $\mathrm{NADH}$ and G3P and at and after $t=12 \mathrm{~min}$ for GAPDH.

We had previously shown that the phosphatase inhibitor vanadate, but not okadaic acid, prevented $\mathrm{Mg}^{2+}$-dependent $\alpha 1$ dephosphorylation in washed cortical membranes (Minier et al., 2000). Therefore, we tested whether these inhibitors were able to modify the time course of the $\mathrm{GABA}_{\mathrm{A}}$ responses: indeed, vanadate $(100 \mu \mathrm{M})$, but not okadaic acid $(10 \mu \mathrm{M})$, prevented rundown (Fig. 5C). These data confirm that rundown depends on a dephosphorylation process and suggest that the same membrane-bound $\mathrm{Mg}^{2+}$-dependent phosphatase is involved in the rundown.

When the glycolytic activity of GAPDH was inactivated by adding iodoacetamide $(500 \mu \mathrm{M})$ to the bath, the preventive effect of $\mathrm{G} 3 \mathrm{P}$ was annihilated and the rundown of the GABA response became again apparent, with a delay of a few minutes (Fig. $6 A$ ). In contrast, rundown prevention by phosphatase inhibition (vanadate) maintaining the phosphorylated state of the $\alpha$ l subunit was not sensitive to iodoacetamide addition (Fig. $6 B$ ). Thus, iodoacetamide does not affect by itself the $\mathrm{GABA}_{\mathrm{A}}$ responses, and the glycolytic function of GAPDH is required for the maintenance of these responses, even in the presence of $7 \mathrm{mM} \mathrm{Mg-ATP}$. These results show that $\mathrm{GABA}_{\mathrm{A}} \mathrm{R}$ function depends on a phosphorylation process fueled by glycolytic substrates and support a role for GAPDH in this mechanism.

A number of phosphatases can be inhibited by fluoride ions present in the pipette milieu. Control experiments in which flu- oride was replaced by chloride did not show any substantial change of the $\mathrm{GABA}_{\mathrm{A}}$ current rundown (data not shown).

\section{Discussion}

The endogenous kinase responsible for the maintenance of $\mathrm{GABA}_{\mathrm{A}} \mathrm{R}$-mediated responses was unknown until now. Here, we identify the receptor kinase candidate P38 associated with the purified $\mathrm{GABA}_{\mathrm{A}} \mathrm{R}$ as being the glycolytic enzyme GAPDH and demonstrate that GAPDH directly phosphorylates identified residues of molecular constructs of the $\mathrm{GABA}_{\mathrm{A}} \mathrm{R} \alpha 1$ long intracellular loop. This unexpected identification implies that this dehydrogenase has additionally a protein kinase activity as already shown in the rabbit muscle (Kawamoto and Caswell, 1986). Indeed, if the phospho-GAPDH formed from the added enzyme did not transfer the phosphate moiety to the $\alpha 1$ subunit, this GAPDH would be expected to compete for ATP with the endogenous kinase and to inhibit the $\alpha 1$ phosphorylation, which is contrary to our observations. Similar to some other kinases, GAPDH autophosphorylates before transferring the phosphate to its target, in agreement with previous findings (Kawamoto and Caswell, 1986); such transfer was favored by the coenzyme $\mathrm{NADH}$, as we have presently observed.

This $\mathrm{GABA}_{\mathrm{A}} \mathrm{R}$ endogenous phosphorylation appears $\alpha 1$ specific. We and others have previously reported that an $\alpha 1$-specific endogenous kinase activity is closely associated with purified $\mathrm{GABA}_{\mathrm{A}} \mathrm{R}$ from bovine cerebral cortex (Sweetnam et al., 1988; Bureau and Laschet, 1995). In addition, a selective anti-bovine $\alpha 1$ monoclonal antibody (Ewert et al., 1990; Sperk et al., 1997) immunoprecipitated $90 \%$ of the $\left[{ }^{3} \mathrm{H}\right]$ muscimol binding sites $(\mathrm{Bu}-$ reau and Laschet, 1995), and a similar proportion of the receptor protein phosphorylated in the presence of ${ }^{32} \mathrm{P}$-labeled ATP (Fig. $2 B$ ), suggesting that phosphate incorporation occurs essentially at the $\alpha 1$ subunit. We also confirm this $\alpha 1$ specificity by showing that the substrate phosphorylated at physiological $\left[\mathrm{Mg}^{2+}\right]$ has an apparent molecular weight corresponding to $\alpha 1$ subunits. We also show that $50 \%$ of radiolabeled species at $51 \mathrm{kDa}$ were immunoprecipitated by a GADPH antibody (Fig. 2C). Taking into account that part of the $\alpha 1$ subunit-GAPDH association could have been disrupted during receptor purification, these data indicate that the anti-GAPDH antibody specifically and quantitatively immunoprecipitates a phosphorylated $\alpha 1$ subunit-GAPDH complex. This is consistent with a high-affinity interaction between GAPDH and the $\alpha 1$ subunit because the addition of exogenous GAPDH enhanced phosphorylation with an estimated $\mathrm{EC}_{50}$ value in the nanomolar range. We do not exclude, however, that other endogenous protein kinases may phosphorylate other $\mathrm{GABA}_{\mathrm{A}} \mathrm{R}$ subunits especially at $\left[\mathrm{Mg}^{2+}\right]$ higher than $10 \mathrm{~mm}$ (Kannenberg et al., 1999) with possibly different functional roles. Phosphorylation on $\beta$ and $\gamma$ subunits by the classical kinases has been reported, but there is no consistent evidence for phosphorylation of $\alpha$ subunits by these kinases. We have previously demonstrated that the endogenous $\mathrm{GABA}_{\mathrm{A}} \mathrm{R}$ phosphorylation occurred on Ser/Thr residues of $\alpha 1$ in an equimolar proportion (Bureau and Laschet, 1995). Accordingly, we identify phosphorylation sites on single Ser and Thr residues within the long intracytoplasmic loop of the $\alpha 1$ subunit.

We show that GAPDH is a receptor-associated protein: GAPDH and $\mathrm{GABA}_{\mathrm{A}} \mathrm{R} \alpha 1$ subunit are in close molecular association because they were copurified, coimmunoprecipitated, and colocalized at the neuronal plasma membrane. This is consistent with observations showing localization of GAPDH in postsynaptic densities (Wu et al., 1997; Moon et al., 1998; Walikonis et al., 2000) and its association with the inner surface of the plasma 
membrane (Daum et al., 1988; Sirover, 1999). However, it is clear from our immunoflurescent imaging that not all the GAPDH located at the membrane is associated with the $\mathrm{GABA}_{\mathrm{A}} \mathrm{R} \alpha 1$ subunit, even if the reverse is true. The fraction of membrane-bound GAPDH that did not colocalize with the $\alpha 1$ subunit could be accounted for by associations with other membrane proteins such as $\left(\mathrm{Na}^{+}, \mathrm{K}^{+}\right)$-ATPase. This ionic pump is fueled at least partially by glycolytic ATP in both neurons and glial cells (Silver et al., 1997). A functional association at the membrane between GAPDH and $\left(\mathrm{Na}^{+}, \mathrm{K}^{+}\right)$-ATPase and a preference for glycolytic ATP were clearly demonstrated in erythrocytes, in cardiac Purkinje cells, and in fast-twitch skeletal muscle (Mercer and Dunham, 1981; Glitsch and Tappe, 1993; Okamoto et al., 2001).

The phosphorylation of $\alpha 1$ subunits in washed brain membranes with $\mathrm{P}_{\mathrm{i}}$ as the sole precursor cannot be explained without the intervention of at least two enzymes of the glycolytic pathway, GAPDH and phosphoglycerate kinase (PGK), working together at the membrane to locally produce the needed ATP. Accordingly, GAPDH and PGK are both present in postsynaptic densities (Wu et al., 1997; Walikonis et al., 2000). Thus, our findings suggest that the GAPDH-PGK association induces a local synthesis of glycolytic ATP to fuel receptor phosphorylation at the postsynaptic density. Interestingly, aldolase and lactate dehydrogenase activities are also found in postsynaptic densities (Wu et al., 1997), allowing the coenzyme $\mathrm{NAD}^{+}$to be regenerated, the glycolysis rate to be increased, and thus the ATP production to be accelerated by the Pasteur effect.

The involvement of GAPDH-dependent phosphorylation of the $\alpha 1$ subunit in the prevention of rundown of $\mathrm{GABA}_{\mathrm{A}}$ responses is supported by the fact that both processes are favored by the addition of GAPDH, its coenzyme NADH, or its substrate G3P. The limited but significant protection against $\mathrm{GABA}_{\mathrm{A}}$ current rundown by GAPDH added to the pipette may be attributable to an increase in the glycolysis turnover or to an increased kinase activity for $\alpha 1$ phosphorylation. Nevertheless, new experimental tools would be helpful to provide more direct evidence that the $\mathrm{GABA}_{\mathrm{A}} \mathrm{R}$ is phosphorylated by GAPDH on the $\alpha 1$ subunit in isolated intact cells or in vivo.

We have previously found a membrane-associated $\mathrm{Mg}^{2+}$. dependent phosphatase that dephosphorylates the $\alpha 1$ subunit and is inhibited by orthovanadate but not by okadaic acid (Minier et al., 2000). This phosphatase is lost during receptor purification. Thus, even in the presence of $\mathrm{Mg}^{2+}$ in sufficient amounts, $\alpha 1$ did not dephosphorylate in purified receptors, whereas this phosphatase is present and active in washed brain membrane preparations. We show that vanadate, but not okadaic acid, mostly prevents rundown, suggesting that the phosphatase active in whole-cell recorded neurons has the same pharmacological profile. Rundown thus reflects a time-dependent shift from the phosphorylated to the nonphosphorylated state because of the higher rate of phosphatase compared with kinase activity. Vanadate is often considered as being a specific inhibitor of phosphotyrosine phosphatases in the micromolar range, whereas $\alpha 1$ is phosphorylated on Ser/Thr residues. However, at higher concentrations, vanadate is no longer residue specific (Shenolikar and Nairn, 1991; Morinville et al., 1998). Moreover, some phosphatases expressed in the brain dephosphorylating Tyr residues, but also Ser/Thr residues, are indeed inhibited by vanadate (Zhao et al., 2001). Finally, we cannot exclude that the $\alpha 1$ Ser/Thrphosphatase(s) activity may depend indirectly on that of a Tyr-phosphatase.

In membranes or cells, the $\mathrm{GABA}_{\mathrm{A}}$ receptor must be phosphorylated to function, and this phosphorylation requires the

\section{Glycolysis steps}<smiles></smiles>

Phosphorylation steps<smiles>CC(C)(C)[N+](=O)[O-]</smiles>

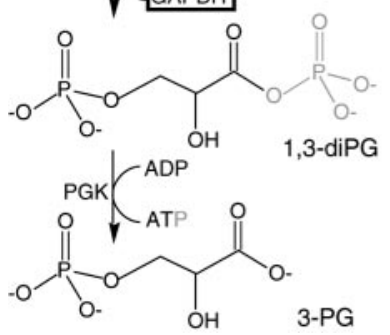

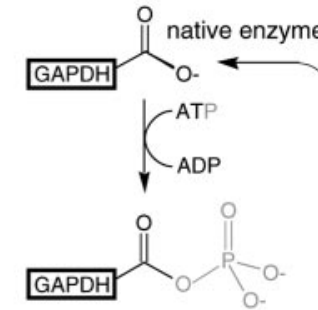

(x2) P-enzyme

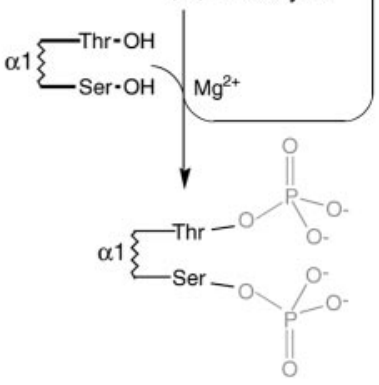

Figure 7. Diagram of the metabolic integration of glycolysis in the $G A B A_{A}$ receptor function. In the present study, we have shown the use of glycolytic ATP for endogenous $G_{A B A_{A} R} \alpha 1$ phosphorylation. The glycolytic substrate G3P is oxidized by the coenzyme NAD ${ }^{+}$, then separates from the enzyme by phosphorolysis in the presence of $\mathrm{Mg}^{2+}$, with incorporation of a phosphate $\left(P_{i}\right)$ forming 1,3-diphosphoglycerate (1,3-diPG). This energy-rich bond is finally used to produce the glycolytic ATP. For the phosphorylation steps, GAPDH autophosphorylates with a preference for this glycolytic ATP. The phospho-GAPDH can then transfer the phosphomoeity in the presence of $\mathrm{Mg}^{2+}$ to the $\alpha 1$ subunit residues Ser and Thr. All these reactions occur on the inner side of the plasma membrane, in the vicinity of the $G A B A_{A} R$. 3-PG, 3-Phosphoglycerate.

Mg-ATP complex; whereas free $\mathrm{Mg}^{2+}$ ions are sufficient to activate the membrane-bound phosphatase. Therefore, varying $\left[\mathrm{Mg}^{2+}\right]$ and $[\mathrm{ATP}]$ and their ratio may be sufficient to modulate the phosphorylation state of $\mathrm{GABA}_{\mathrm{A}} \mathrm{R}$ and thus its response to the agonist. Yet, it is difficult to know how free intracellular $\mathrm{Mg}^{2+}$ is regulated, especially near the inner side of the plasma membrane. We do not rule out the possibility that $\left[\mathrm{Mg}^{2+}\right]_{\mathrm{i}}$ remains constant; but even in such case, varying the glycolysis rate (and thus the level of ATP available) may be sufficient for $\mathrm{GABA}_{\mathrm{A}}$ response modulation.

The dehydrogenase inhibitor iodoacetamide did not prevent the kinase activity of GAPDH and did not directly alter the $\mathrm{GABA}_{\mathrm{A}} \mathrm{R}$ function. Therefore, the rapid and marked effect of iodoacetamide on the rundown of GABA responses observed when the intracellular [ATP] was $7 \mathrm{~mm}$ shows that the ATP required for the maintenance of the GABA responses is essentially the glycolytic ATP, probably produced locally at the membrane. Such feature presents the advantage of a local and fast ATP production, and a regulation independent of oxidative energy production. Furthermore, the association of glycolytic enzymes with the receptor complex avoids or limits ATP diffusion. Indeed, it was shown that glycolytic ATP is not in equilibrium with the bulk ATP in the skeletal muscle triads (Han et al., 1992). Our data suggest a similar property for the $\mathrm{GABA}_{\mathrm{A}}$ receptor function.

Considering the preference for glycolytic instead of oxidative ATP for $\mathrm{GABA}_{\mathrm{A}} \mathrm{R}$ phosphorylation, we propose the following 
concept of integrated membrane machinery for sustaining fast inhibitory transmission (Fig. 7). The steps of glycolysis required for ATP production are those catalyzed by GAPDH and PGK. GAPDH itself is not phosphorylated in glycolytic reactions, and ATP is not a substrate in this oxidation-reduction cycle. For receptor phosphorylation, there is no need for ATP to diffuse because it can be channeled back, allowing GAPDH to autophosphorylate with a preference for this locally produced glycolytic ATP. The phospho-GAPDH has the capacity to transfer the phospho-moiety in the presence of $\mathrm{Mg}^{2+}$ to the $\mathrm{GABA}_{\mathrm{A}} \mathrm{R} \alpha 1$ subunit residues Ser and Thr that are substrates for the kinase activity of receptor-associated GAPDH, this transfer being enhanced by NADH produced by the dehydrogenase activity. All these reactions occur at the inner side of the plasma membrane, in the vicinity of the $\mathrm{GABA}_{\mathrm{A}} \mathrm{R}$ within a macrocomplex.

Finally, because the GABAergic function is glycolysis dependent, it must be modulated by the $\mathrm{NAD}^{+} / \mathrm{NADH}$ and $\mathrm{ATP} /$ $\left(\mathrm{ADP}+\mathrm{P}_{\mathrm{i}}\right)$ ratios in conjunction with the appropriate $\mathrm{GAPDH}$ substrate concentrations. Thus, any pathophysiological state interfering with the energetic metabolism (epilepsy, anoxia, etc.) should alter the efficiency of synaptic GABAergic inhibition. Indeed, it has been shown using positron emission tomography that the administration of a $\mathrm{GABA}_{\mathrm{A}}$ agonist increases brain glucose metabolism in normal subjects (Peyron et al., 1994a), even more in temporal lobe epilepsy patients, in which a diffuse hypometabolism is usually present (Peyron et al., 1994b). Therefore, the mechanisms regulating such glycolysis-dependent phosphorylation may be the targets for the development of new drugs in various brain pathologies.

\section{References}

Ames 3rd A, Li YY, Heher EC, Kimble CR (1992) Energy metabolism of rabbit retina as related to function: high cost of $\mathrm{Na}^{+}$transport. J Neurosci 12:840-853.

Brandon NJ, Delmas P, Hill P, Smart TG, Moss SJ (2001) Constitutive tyrosine phosphorylation of the $\mathrm{GABA}_{\mathrm{A}}$ receptor $\gamma 2$ subunit in the rat brain. Neuropharmacology 41:745-752.

Browning MD, Bureau M, Dudek EM, Olsen RW (1990) Protein kinase C and cAMP-dependent protein kinase phosphorylate the $\beta$ subunit of the purified $\gamma$-aminobutyric acid A receptor. Proc Natl Acad Sci USA 87:1315-1318.

Bureau MH, Laschet JJ (1995) Endogenous phosphorylation of distinct $\gamma$-aminobutyric acid type A receptor polypeptides by Ser/Thr and Tyr kinase activities associated with the purified receptor. J Biol Chem 270:26482-26487.

Chen QX, Stelzer A, Kay AR, Wong RKS (1990) GABA receptor function is regulated by phosphorylation in acutely dissociated guinea-pig hippocampal neurones. J Physiol (Lond) 420:207-221.

Daum G, Keller K, Lange K (1988) Association of glycolytic enzymes with the cytoplasmic side of the plasma membrane of glioma cells. Biochim Biophys Acta 939:227-281.

Ercolani L, Florence B, Denaro M, Alexander M (1988) Isolation and complete sequence of a functional human glyceraldehyde-3-phosphate dehydrogenase gene. J Biol Chem 263:15335-15341.

Ewert M, Shivers BD, Lüddens H, Möhler H, Seeburg PH (1990) Subunit selectivity and epitope characterization of mAbs directed against the $\mathrm{GABA}_{\mathrm{A}}$ /benzodiazepine receptor. J Cell Biol 110:2043-2048.

Fox PT, Raichle ME, Mintun MA, Dence C (1988) Nonoxidative glucose consumption during focal physiologic neural activity. Science 241:462-464.

Fuhrmann JC, Kins S, Rostaing P, El Far O, Kirsch J, Sheng M, Triller A, Betz H, Kneussel M (2002) Gephyrin interacts with dynein light chains 1 and 2, components of motor protein complexes. J Neurosci 22:5393-5402.

Glitsch HG, Tappe A (1993) Thhe Na+/K+ pump of cardiac Purkinje cells is preferentially fuelled by glycolytic ATP production. Pflügers Arch 422:380-385.

Gyenes M, Wang Q, Gibbs TT, Farb DH (1994) Phosphorylation factors control neurotransmitter and neuromodulator actions at the gammaaminobutyric acid type A receptor. Mol Pharmacol 46:542-549.

Han JW, Thieleczek R, Varsanyi M, Heilmeyer LMJr (1992) Compartmentalized ATP synthesis in skeletal muscle triads. Biochemistry 31:377-384.

Huang R, Dillon GH (1998) Maintenance of recombinant type A $\gamma$-aminobutyric acid receptor function: role of protein tyrosine phosphorylation and calcineurin. J Pharmacol Exp Ther 286:243-255.

Ikemoto A, Bole DG, Ueda T (2003) Glycolysis and glutamate accumulation into synaptic vesicles. Role of glyceraldehyde phosphate dehydrogenase and 3-phosphoglycerate kinase. J Biol Chem 278:5929-5940.

Jones MV, Westbrook GL (1997) Shaping of IPSCs by endogenous calcineurin activity. J Neurosci 17:7626-7633.

Kaneda M, Farrant M, Cull-Candy SG (1995) Whole-cell and singlechannel currents activated by GABA and glycine in granule cells of the rat cerebellum. J Physiol (Lond) 485:419-435.

Kannenberg K, Schaerer MT, Fuchs K, Sieghart W, Sigel E (1999) A novel serine kinase with specificity for $\beta 3$-subunits is tightly associated with $\mathrm{GABA}_{\mathrm{A}}$ receptors. J Biol Chem 274:21257-21264.

Kawamoto RM, Caswell AH (1986) Autophosphorylation of glyceraldehydephosphate dehydrogenase and phosphorylation of protein from skeletal muscle microsomes. Biochemistry 25:656-661.

Kirkness EF, Bovenkerk CF, Ueda T, Turner AJ (1989) Phosphorylation of $\gamma$-aminobutyrate (GABA)/benzodiazepine receptors by cyclic AMPdependent protein kinase. Biochem J 259:613-616.

Krishek BJ, Xie X, Blackstone C, Huganir RL, Moss SJ, Smart TG (1994) Regulation of $\mathrm{GABA}_{\mathrm{A}}$ receptor function by protein kinase $\mathrm{C}$ phosphorylation. Neuron 12:1081-1095.

Krupp J, Feltz P (1993) Synaptic- and agonist-induced chloride currents in neonatal rat sympathetic preganglionic neurones in vitro. J Physiol (Lond) 471:729-748.

Kulbe KD, Jackson KW, Tang J (1975) Structural evidence for a liverspecific glyceraldehyde-3-phosphate dehydrogenase. Biochem Biophys Res Commun 67:35-42.

Levitan IB (1999) Modulation of ion channels by protein phosphorylation. How the brain works. Adv Second Messenger Phosphorylation Res 33:3-22.

Lin Y-F, Browning MD, Dudek EM, Macdonald RL (1994) Protein kinase C enhances recombinant bovine $\alpha 1 \beta 1 \gamma 2 \mathrm{~L} \mathrm{GABA}_{\mathrm{A}}$ receptor whole-cell currents expressed in L929 fibroblasts. Neuron 13:1421-1431.

Machu TK, Firestone JA, Browning MD (1993) $\mathrm{Ca}^{2+} /$ calmodulindependent protein kinase II and protein kinase C phosphorylate a synthetic peptide corresponding to a sequence that is specific for the gamma $_{2 \mathrm{~L}}$ subunit of the $\mathrm{GABA}_{\mathrm{A}}$ receptor. J Neurochem 61:375-377.

McDonald BJ, Moss SJ (1994) Differential phosphorylation of intracellular domains of gamma-aminobutyric acid type A receptor subunits by calcium/calmodulin type 2-dependent protein kinase and cGMP-dependent protein kinase. J Biol Chem 269:18111-18117.

McDonald BJ, Amato A, Connolly CN, Benke D, Moss SJ, Smart TG (1998) Adjacent phosphorylation sites on $\mathrm{GABA}_{\mathrm{A}}$ receptor $\beta$ subunits determine regulation by cAMP-dependent protein kinase. Nat Neurosci 1:23-28.

Mercer RW, Dunham PB (1981) Membrane-bound ATP fuels the Na/K pump. Studies on membrane-bound glycolytic enzymes on inside-out vesicles from human red cell membranes. J Gen Physiol 78:547-568.

Minier F, Laschet JJ, Evrard B, Bureau MH (2000) Endogenous phosphorylation of the $\mathrm{GABA}_{\mathrm{A}}$ receptor protein is counteracted by a membraneassociated phosphatase. Neurochem Int 36:499-506.

Moon JI, Dae Kim J, Wook Jung Y, Hyun Ko B, Jin I, Moon IS (1998) Identification of glyceraldehyde-3-phosphate dehydrogenase by protein sequencing in the rat postsynaptic density fraction. Mol Cell 8:359-365.

Morinville A, Maysinger D, Shaver A (1998) From Vanadis to Atropos; vanadium compounds as pharmacological tools in cell death signalling. Trends Pharmacol Sci 19:452-560.

Moss SJ, Smart TG (1996) Modulation of amino acid-gated ion channels by protein phosphorylation. Int Rev Neurobiol 39:1-52.

Moss SJ, Doherty CA, Huganir RL (1992a) Identification of the cAMPdependent protein kinase and protein kinase $\mathrm{C}$ phosphorylation sites within the major intracellular domains of the $\beta_{1}$, gamma 2 , and gamma 2 subunits of the gamma-aminobutyric acid type A receptor. J Biol Chem 267:14470-14476.

Moss SJ, Smart TG, Blackstone CD, Huganir RL (1992b) Functional modulation of $\mathrm{GABA}_{\mathrm{A}}$ receptors by cAMP-dependent protein phosphorylation. Science 257:661-665. 
Moss SJ, Gorrie GH, Amato A, Smart TG (1995) Modulation of $\mathrm{GABA}_{\mathrm{A}}$ receptors by tyrosine phosphorylation. Nature 337:344-348.

Nusser Z, Sieghart W, Mody I (1999) Differential regulation of synaptic $\mathrm{GABA}_{\mathrm{A}}$ receptors by cAMP-dependent protein kinase in mouse cerebellar and olfactory bulb neurones. J Physiol (Lond) 521:421-435.

Okamoto K, Wang W, Rounds J, Chambers EA, Jacobs DO (2001) ATP from glycolysis is required for normal sodium homeostasis in resting fast-twitch rodent skeletal muscle. Am J Physiol Endocrinol Metab 281:E479-E488.

Peyron R, Le Bars D, Cinotti L, Garcia-Larrea L, Galy G, Landais P, Millet P, Lavenne F, Froment JC, Krogsgaard-Larsen P, Mauguière F (1994a) Effects of $\mathrm{GABA}_{\mathrm{A}}$ receptors activation on brain glucose metabolism in normal subjects and temporal lobe epilepsy (TLE) patients. A positron emission tomography (PET) study. Part I: brain glucose metabolism is increased after $\mathrm{GABA}_{\mathrm{A}}$ receptors activation. Epilepsy Res 19:45-54.

Peyron R, Cinotti L, Le Bars D, Garcia-Larrea L, Galy G, Landais P, Millet P, Lavenne F, Froment JC, Krogsgaard-Larsen P, Mauguière F (1994b) Effects of $\mathrm{GABA}_{\mathrm{A}}$ receptors activation on brain glucose metabolism in normal subjects and temporal lobe epilepsy (TLE) patients. A positron emission tomography (PET) study. Part II: the focal hypometabolism is reactive to $\mathrm{GABA}_{\mathrm{A}}$ agonist administration in TLE. Epilepsy Res 19:55-62.

Poisbeau P, Cheney MC, Browning MD, Mody I (1999) Modulation of synaptic $\mathrm{GABA}_{\mathrm{A}}$ receptor function by PKA and PKC in adult hippocampal neurons. J Neurosci 19:674-683.

Robello M, Amico C, Cupello A (1998) Cerebellar granule cell GABA $\mathrm{A}$ receptors studied at the single-channel level: modulation by protein kinase G. Biochem Biophys Res Commun 253:768-773.

Shenolikar S, Nairn AC (1991) Protein phosphatases: recent progress. Adv Second Messenger Phosphoprotein Res 23:1-121.

Silver A, Deas J, Erecinska M (1997) Ion homeostasis in brain cells: differences in intracellular ion responses to energy limitation between cultured neurons and glial cells. Neuroscience 78:589-601.

Sirover MA (1999) New insights into an old protein: the functional diversity of mammalian glyceraldehyde-3-phosphate dehydrogenase. Biochim Biophys Acta 1432:159-184.

Sokoloff L (1977) Relation between physiological function and energy metabolism in the central nervous system. J Neurochem 29:13-26.

Sperk G, Schwartzer C, Tsunashima K, Fuchs K, Sieghart W (1997) GABA receptor subunits in the rat hippocampus I: immunochemical distribution of 13 subunits. Neuroscience 80:987-1000.

Stauber GB, Ransom RW, Dilber AI, Olsen RW (1987) The gammaaminobutyric acid-benzodiazepine receptor protein from rat brain: largescale purification and preparation of antibodies. Eur J Biochem 167:125-133.

Stelzer A, Kay AR, Wong RKS (1988) $\mathrm{GABA}_{\mathrm{A}}$-receptor function in hippocampal cells is maintained by phosphorylation factors. Science 241:339-341.

Sweetnam PM, Lloyd J, Gallombardo P, Malison RT, Gallager DW, Tallman JF, Nestler EJ (1988) Phosphorylation of the GABA $/$ /benzodiazepine receptor $\alpha$ subunit by a receptor-associated protein kinase. J Neurochem 51:1274-1284.

Unwin N (1993) Neurotransmitter action: opening of ligand-gated ion channels. Cell [Suppl] 72:31-41.

Walikonis RS, Jensen ON, Mann M, Provance Jr DW, Mercer JA, Kennedy MB (2000) Identification of proteins in the postsynaptic density fraction by mass spectroscopy. J Neurosci 20:4069-4080.

Wan Q, Man HY, Braunton J, Wang W, Salter MW, Becker L, Wang YT (1997) Modulation of $\mathrm{GABA}_{\mathrm{A}}$ receptor function by tyrosine phosphorylation of $\beta$ subunits. J Neurosci 13:5062-5069.

Wu K, Aoki C, Elste A, Rogalski-Wilk AA, Siekevitz P (1997) The synthesis of ATP by glycolytic enzymes in the postsynaptic density and the effect of endogenously generated nitric oxide. Proc Natl Acad Sci USA 94: 13273-13278.

Zhao R, Qi Y, Chen J, Zhao ZJ (2001) FYVE-DSP2, a FYVE domaincontaining dual specificity protein phosphatase that dephosphorylates phosphatidylinositol 3-phosphate. Exp Cell Res 265:329-338. 